\title{
The 'Future Use' of the Present Progressive in English: Subjectification of the Progressive and an Analysis in Terms of Cognitive Grammar
}

\author{
Souma Mori ${ }^{1}$ \\ ${ }^{1}$ Doctoral Program in Literature and Linguistics, University of Tsukuba, Japan \\ Correspondence: Souma Mori, Doctoral Program in Literature and Linguistics, University of Tsukuba, 1-1-1, \\ Tennoudai, Tsukuba-shi, Ibaraki Prefecture, Japan. E-mail: englishenglishmori@hotmail.co.jp
}

Received: November 22, 2015 Accepted: December 13, 2015 Online Published: January 31, 2016

doi:10.5539/ijel.v6n1p1 URL: http://dx.doi.org/10.5539/ijel.v6n1p1

\begin{abstract}
This study deals with the present progressive with future time reference. The aim of this paper is to show that the 'future use' of the present progressive is, diachronically, subjectified. After identifying the concept of subjectification defined by Traugott $(1989,1995,2003,2010)$ and Traugott \& Dasher (2002), I show that the 'future use' is more subjective than the use of present ongoing activities, and argue that the 'future use' has been modeled in terms of subjectification. Moreover, this paper argues that, although the 'future use' does not refer to physically ongoing events, in the 'future use' the situation can be viewed as 'in progress' cognitively, and proposes a new account of the 'future use' based on the framework of Cognitive Grammar, as laid out by Langacker (2008). Thereby, it is shown that the use of present ongoing activities and the 'future use' are both based on the same cognitive foundation, and the difference lies in which portion is profiled.
\end{abstract}

Keywords: the present progressive, the future use, ongoing activities, subjectification, Cognitive Grammar

\section{Introduction}

As is well known, the present progressive in English can refer to future time. So far, numerous studies on this 'future use' of the present progressive have been made (e.g., Jespersen (1924), Poutsma (1926), Kruisinga (1931), Allen (1966), Leech (1971, 1987, 2004), Goodman (1973), Close (1975), Wekker (1976), Dowty (1977), Huddleston (1977), Smith (1981, 1997), Prince (1982), Quirk et al. (1985), Hirtle \& Curat (1986), Palmer (1987), Declerck (1991, 2006), Leech \& Svartvik (1994, 2002), Biber et al. (1999), Huddleston \& Pullum (2002), Hundt (2004), Dixon (2005), Nesselhauf (2007), Leech et al. (2009), Wada (2009), Bergs (2010), De Wit \&Brisard (2014)). According to Declerck (1991, p. 92, 2006, p. 184), the 'future use' of the present progressive "implies less certainty than the simple present: it refers to a present plan which may possibly still be altered, while the simple present denotes a plan or arrangement that is regarded as unalterable." (Note 1, 2)

The aim of this paper is to explore the 'future use' of the present progressive by taking into consideration the concept of subjectification as defined by Traugott (1989, 1995, 2003, 2010), Traugott \& Dasher (2002), Hopper \& Traugott (2003), Brinton \& Traugott (2005), and Brinton (2008). Although Declerck (1991, 2006) and other studies are trying to precisely describe the semantic nature of the 'future use,' these works do not take account of approach of subjectification. It is argued here that the 'future use' of the present progressive has undergone subjectification. This paper provides a simple, convincing, and new account of the 'future use,' in terms of subjectification.

And further, although it is certain that the 'future use' does not denote physically ongoing events, this paper argues that in the 'future use' events are regarded as cognitively ongoing. And, the present paper proposes an analysis of the 'future use,' in which this is illustrated, based on the theory of Langacker's (2008) Cognitive Grammar.

This paper is organized as follows. Section 2 shows previous work on the 'future use' of the progressive. Section 3 introduces the concept of subjectification, which is a key idea to this study. In section 4 it is argued that the 'future use' is more subjective than the use of ongoing activities, and is, diachronically, subjectified. In section 5 we introduce the basic tenets of Langacker's $(1987,2001,2008)$ Cognitive Grammar, and propose an account of the 'future use,' basing ourselves on the framework of Cognitive Grammar by Langacker (2008). In section 6, 
finally, we offer our concluding remarks.

\section{Review of Previous Studies}

Subsection 2.1 demonstrates, by observing descriptive definitions of the 'future use' of the present progressive shown by previous studies, that it is very difficult to descriptively define the nature of the future referred to by the progressive and the situation in which the present progressive with future time reference is used. Subsection 2.2 shows that the present progressive can be used not only in the near future but also in the distant future. In subsection 2.3 it is shown that, in the 'future use' of the progressive, verbs of not only motion but also non-motion can occur.

\section{1 'Difficult' Semantic Definition of the Future Use of the Present Progressive}

In this subsection, first of all, let us survey works which offer a descriptive definition of the 'future use' of the present progressive. According to Leech $(2004$, p. 61$)$, for instance, a reasonably precise definition of the present progressive with future reference is: "future event anticipated by virtue of a present plan, programme or arrangement." Here are examples:

(1) She's getting married this spring.

(2) The Chelsea-Arsenal match is being played next Saturday.

(3) We're having fish for dinner.

(4) I'm inviting several people to a party.

((1)-(4): Leech, 2004, p. 61)

Each example above has an implication of an arrangement already made: "the marriage has been arranged," "the football match has been fixed," "the menu has been chosen," and "the party has already been decided on" (Leech, 2004, pp. 61-62).

Hirtle \& Curat (1986, p. 65) state: "a number of scholars characterize the 'future' use of the progressive in terms of 'arrangement,' 'plan,' 'program' and the like." (Note 3) Huddleston \& Pullum (2002, p. 171), however, say that the future use of the progressive is not limited to 'arrangement,' 'plan,' and 'program':

(5) I'm phoning her tonight. (Huddleston \& Pullum, 2002, p. 171)

According to Huddleston \& Pullum (2002), in (5), "it could be that I have simply formed the intention to phone her (without consulting her or anyone else about the matter)." Nesselhauf (2007, p. 203) too states that some instances in the 'future use' of the present progressive indicate mere intention without any kind of social arrangement.(Note 4) Furthermore, let us observe the following:

(6) "That is the fever, darling. Listen, I'm coming up to you! I'm leaving now, at once. No don't protest."

“All right, I'm glad you're coming, Mark. I dare say—I'm not so brave as I thought." (Hirtle \& Curat, 1986, p. 75)

Hirtle \& Curat (1986, p. 75) say that the first progressive in (6) does not evoke a 'programmed' event, nor does it suggest 'intention.' They state, moreover, that "as for I'm leaving, it could be taken as evoking either a 'decision' nuance or 'intention." (Hirtle \& Curat, 1986, p. 76)

In this subsection, we have seen that the present progressive for future time reference suggests 'arrangement,' 'plan,' 'program,' 'intention,' and 'decision.' In this way, we can state: it is very difficult to precisely describe the nature of the future indicated by the progressive and the situation in which the future use of the present progessive is used. As will be presented in sections 3-4 later, however, this paper attempts to offer a simple and unified account for descriptive studies of the 'future use,' in terms of subjectification (Note 5,6).

\subsection{Distant Future}

The progressive tends to be used for the relatively near future (see Huddleston \& Pullum (2002, p. 171)). In fact, Leech (2004, pp. 61-62) states that "the notion of 'fixed arrangement' comes to be associated with the near rather than distant future." Here, note that Leech $(2004$, p. 62$)$ describes the future use as: "the near rather than distant future." The progressive, however, can also be used for an event in the distant future, as in the following:

(7) After a year in Vienna I' $m$ working with Dr. Hochberg. (Allen, 1966, p. 215)

(8) It's expiring in five years. (Huddleston \& Pullum, 2002, p. 171)

(9) I'm leaving the university in two years' time. [when I've finished my studies] (Quirk et al., 1985, p. 215)

In (7)-(9) above, after a year, in five years, and in two years' time are used respectively. These adverbials are by 
no means expressions referring to the near future. Rather, they seem to refer to the distant future. In this way, the present progressive can be used for not only the near future but also the distant future.

\subsection{Non-motion Verbs}

With respect to the verbs that occur in the 'future use' of the progressive, Nesselhauf (2007, p. 198) states that this type of construction is predominantly used with "motion verbs" or "verbs of movement" (cf. Goossens (1994), Bergs (2010)). But, there is no restriction to such verbs, as is exemplified in:

(10) I'm staying at the Gardners next week. (Declerck, 1991, p. 92)

(11) We are owning the farm tomorrow. (Smith, 1981, p. 369)

The verbs used in the examples above (i.e. stay and own) are not motion verbs or verbs of movement (cf. Palmer (1987, pp. 64-65)). In this way, in the 'future use' of the progressive, not only motion verbs but also non-motion verbs can be used.

In this subsection, we have seen that the verbs that occur in the 'future use' of the present progressive are not restricted to verbs of motion or movement, that is to say, that verbs of non-motion or non-movement can occur in the 'future use' of the present progressive.

\section{Subjectification}

Since Benveniste (1971 [1958]) the topic of subjectivity has been discussed in many ways, and subjectification has been defined in different ways (cf. Traugott (1989, 1995, 2003, 2010), Traugott \& König (1991), Fitzmaurice (1998), Schwenter \& Traugott (2000), Traugott \& Dasher (2002), Hopper \& Traugott (2003), Brinton \& Traugott (2005), Brinton (2008)). In Traugott (2010) it is assumed that a distinction is to be made between subjectivity and subjectification: subjectivity marks a synchronic state, and subjectification a diachronic process. In this section we will explore the concept of subjectification. Subjectification is a notion on which a way to account for the 'future use' of the progressive, developed in the present paper, is based, and plays a key role in providing a new account for the 'future use,' so that the concept of subjectification needs to be explained. (Note 7) According to Traugott (1995), the term 'subjectification' refers to:

(12) "a pragmatic-semantic process whereby 'meanings became increasingly based in the speaker's subjective belief state/attitude toward the proposition,' in other words, towards what the speaker is talking about" (Traugott, 1995, p. 31)

Traugott \& Dasher (2002, p. 225) and Traugott (2003, 2010), furthermore, argue that expressions can be organized along a cline of subjectivity as in (13) below (Note 8):

(13) non-/less subjective $>$ subjective

As examples of subjectification Traugott $(1995,2010)$ has adduced the development of be going to from expressions of motion with intent to act in the sixteenth century to those of speaker's assessment of the future, and the semantic change of while from 'during' (Early Middle English) to 'although' (Early Modern English). Look at the sentences in (14) and (15) below:

(14) a. Mary is going to visit her agent. (progressive motion verb go, purposive to)

b. Mary is going to/gonna visit her agent. (quasi-auxiliary)

(15) a. Mary read while Bill sang. (temporal connective)

b. Mary liked oysters while Bill hated them. (concessive connective)

((14)-(15): Traugott, 1995, p. 31)

Of each of these pairs, a form or phrase in (b) developed historically later than that in (a). First, let us look at $(14 a, b)$. Example (14a) is an expression of motion with intent to act; example (14b) is an expression of speaker's assessment of the future. (14a) is an example of constructions with purposive non-finite complements. (14b), on the other hand, involves the reanalysis from progressive aspect and a purposive to-infinitive to the auxiliary be going to, and can undergo phonological reduction (see Dahl (2000), Hopper \& Traugott (2003, pp. 2-3)). Next, take a look at (15a, b). While in (15a) indicates the temporal sense 'during.' While in (15b), on the other hand, indicates the concessive sense 'although.' In this way, in previous studies it is shown that a use in (b) is more subjective in meaning than its cognate in (a), and a use in (b), which has followed a form or phrase in (a) historically, is subjectified. (Note 9) Also, as an example of subjectification Traugott (2010) has adduced epistemic will derived from a main verb of desire or volition (cf. Aijmer (1985), Bybee et al. (1994, p. 16), Harris \& Campbell (1995, p. 92), Lehmann (1995, p. 28) and Campbell (2001) too state that English will 
originally meant 'want'). Look at sentences (16) and (17) below:

(16) Ic wille mid flode folc acwellan

'I “will” with flood kill people' (Genesis 1296 (Visser, 1969, p. 1677))

(17) I am aferd there wylle be something amyss

(c.1450, Coventry Myst.; Assumption 349 (Visser, 1969, p. 1701))

Sentence (16) is an example of volition of the subject, and sentence (17) is an example in which epistemic will is found. In this way, the sense of will has changed from volition of the subject to an epistemic sense (cf. Kranich (2010)). Epistemic modality is concerned with the speaker's attitude to the truth-value or factual status of the proposition (see Lyons $(1977,1995)$, Palmer $(1987,1990,2001,2003)$ ). Thus, as Traugott (2010) says, we can refer to the semantic change of will like the shift from (16) to (17) as subjectification (Note 10).

\section{The 'Future Use' of the Present Progressive}

In the last section we introduced the concept of subjectification and observed some instances of subjectification. Here, I argue that the 'future use' of the present progressive has undergone subjectification. Although Leech et al. (2009, p. 133) speak of "a metonymic extension of the basic meaning of the progressive," the purpose of this section is to show that it is reasonable to think that the 'future use' has been subjectified diachronically.

"In OE, the present participial morpheme, -ende, was inflectional and agreed in number, case, and gender with the N modified" (Brinton \& Traugott, 2005, p. 113):

(18) $Æ$ [th] elwulf ferde to Rome and [th] ær wæs xii mona [th] wuniende. $\left(O E D^{2}, \mathrm{Be} 15 \mathrm{a}\right)$

A lot of studies have been made about the replacement of the V-ende form by V-ing and the development of be + -ing into the progressive (see, e.g., Nickel (1966), Visser (1963-1973), Denison (1993), Bybee et al. (1994), Warner (1995)). In later OE, -ende was often weakened to -inde, and this became the regular Southern form of the ending in Early ME. From the end of the 12th century there was a growing tendency to confuse -inde, phonetically or scribally, with -inge (see $O E D^{2}$, ing 2):

(19) Syngynge he was, or floytynge, al the day

'He was singing, or fluting all day' (Chaucer, General Prologue 91)

In $\mathrm{ME}$, -ing replaced -ende partly under the influence of another nominal derivative, -ung/-ing. In Brinton \& Traugott's (2005, p. 115) words, "over a period of about a thousand years, a new discontinuous aspect marker be -ing came into being to mark progressive aspect." Given the fact that in Modern English -ing forms have the use of present ongoing activities and the 'future use', we can see that the use of present ongoing activities preceded the 'future use,' i.e. that the development of the 'future use' of the present progressive followed the use of the progressive aspect. In fact, $O E D^{2}$ (Be 15) adduces as an initial example of be-verbs with the present participle form in ME, the following sentence, which indicates an ongoing activity.

(20) he was a-fighting

'he was fighting'

As Leech et al. (2009, p. 132) state, on the other hand, the present progressive with future time reference was certainly available in Early Modern English. In fact, Rissanen (1999, pp. 222-223) cites the following (21) as an example in which the present progressive refers to future time in Early Modern English.

(21)To-morrow ... Don Alphonso With other Gentlemen of good esteeme, Are iournying to salute the Emperor (Shakespeare Two Gentlemen of Verona I.iii)

As was shown in section 2.1, 'arrangement,' 'plan,' 'program,' 'intention,' and 'decision' can be used for describing the meaning of the 'future use' of the progressive and the situation in which the 'future use' is used. The words, 'arrangement,' 'plan,' 'program,' 'intention,' and 'decision,' represent the speaker's attitudes and beliefs, compared with 'present ongoing activities.' In order to confirm this, let us consult monolingual dictionaries and look at the semantic definitions of 'arrangement, 'plan,' 'program,' 'intention,' and 'decision':

(22) a. 'arrangement': the things that you must organize so that an event, meeting etc can happen $\left(L D C E^{3}\right)$

b. 'plan': something that you intend to do or achieve $\left(O A L D^{6}\right)$

c. 'program': a plan of things that will be done or included in the development of something $\left(O A L D^{6}\right)$

d. 'intention': an idea or plan of what you are going to do $\left(C O B U I L D^{4}\right)$

e. 'decision': a choice or judgment that you make after a period of discussion or thought $\left(L D C E^{3}\right)$ 
The parts underlined in (22a-e) above denote more subjective belief/attitude than ongoing activities. For example, you must organize so that an event, meeting etc can happen in (22a) represents more subjective belief/attitude than ongoing activities, because must is an expression of modality, and the so that-clause is an expression of purpose. In (22b) intend obviously expresses subjective belief/attitude; thereby, 'program' and 'intention' in (22c, d) can be regarded as terms for more subjective belief/attitude than ongoing activities. In (22e), judgment and thought are evidently terms for belief, compared with ongoing activities. This is why we can state that the 'future use' of the progressive has been recruited to encode and regulate the speaker's attitudes and beliefs, that is to say, the 'future use' has undergone subjectification. A phenomenon like this is very similar to the development of the auxiliary be going to in that the meaning of expressions shifted from ongoing motion to speaker's assessment of the future (see section 3). In this way, we have seen that the 'future use' of the progressive is an instance of subjectification. (Note 11) Thus, the present paper concludes that the progressive with future time reference has been established by undergoing subjectification.

Here, again, take a look at examples (1)-(5), repeated as (23)-(27) below:

(23) She's getting married this spring.

(24) The Chelsea-Arsenal match is being played next Saturday.

(25) We're having fish for dinner.

(26) I' $m$ inviting several people to a party.

(27) I'm phoning her tonight.

As we saw in section 1, in examples (23)-(27) there is the implication of an arrangement already made: for example, in (23), the marriage has been arranged; in (24), the football match has been fixed; in (25), the menu has been chosen; in (26), the party has already been decided on. In (27), further, it could be that I have simply formed the intention to phone her. Thus, it follows that the future referred to by (23)-(27) suggests 'arrangement' or 'intention.' Since 'arrangement' and 'intention' are terms for subjectivity (see (22a, d)), we can state that examples like (23)-(27) are subjectified. Incidentally, as is mentioned in note 11, it is certain that examples (23)-(27) are what is observed in speech-based and informal written registers.

\section{A Langackerian Account of the 'Future Use'}

In the last section we showed that the present progressive with future time reference is more subjective than the use of present ongoing activities, and argued that the 'future use' of the present progressive was modeled through subjectification (Note 12). At this point, the question arises whether or not in the 'future use' the speaker regards nothing as in progress. Indeed, the present progressive form in the 'future use' does not express situations in which activities are physically ongoing, that is, does not indicate progressive aspect. In the 'future use' of the progressive, however, the situation is, cognitively, viewed as in progress. As endorses this view, De Wit \& Brisard (2014, p. 74) states that the 'future use' of the progressive represents the situation as part of immediate reality. (Note 13) Furthermore, Hirtle (1967, pp. 95-96) remarks that the situations described by the verb can be construed as already 'in progress' at the time of utterance. (see Leech et al., 2009, p. 133) In addition, citing example (28) below, Kranich (2013, p. 15) states 'the 'near future' use of the present progressive often denotes a situation which is firmly planned or may already be conceptualized as in progress, e.g., because preparatory activities are already ongoing."

(28) The day ended with the sad news that Dick is leaving to go to a rehabilitation center in N.H., for children.

A piece of linguistic evidence whereby in the 'future use' the situation is viewed as cognitively 'in progress,' even though it does not indicate progressive aspect, is that it can be used with adverbials for distant future, as in (7)-(9):

(29) After a year in Vienna I' $m$ working with Dr. Hochberg.

(30) It's expiring in five years.

(31) I'm leaving the university in two years'time. [when I've finished my studies]

As we saw in section 2.2, although the 'future use' of the present progressive tends to be used for the near future, it can also be used with adverbials for distant future. To be sure, the 'future use' is commonly used for the near future, but the fact that it can be used for the distant future indicates that, in using it, the situation is regarded as under way cognitively enough that the situation can be viewed as 'in progress' in the distant future as well as in the near future.

Another piece of linguistic evidence whereby in the 'future use' of the present progressive the situation is viewed 
as cognitively 'in progress' is the fact that in the 'future use' non-motion verbs can be used. Again, look at examples (10) and (11):

(32) I'm staying at the Gardners next week.

(33) We are owning the farm tomorrow.

As was argued in section 2.3, not only motion verbs but non-motion ones can be used in the 'future use.' Verbs of non-motion and non-movement cannot be used in the progressive basically. Hence, when non-motion verbs are used in ing-form, we should think that the situation is viewed as in progress strongly. Thus, we can say that in the 'future use' the situation is viewed, cognitively, as in progress.

Based on the view above, it can be accounted for why judgments vary as to the acceptability of a sentence like (34); sentence (34) is originally from Goodman (1973). Wekker (1976), Leech (1987, 2004) and Dixon (2005, p. 213) asterisk sentences like this, while Huddleston \& Pullum (2002, p. 171) maintain the anomaly of examples like (34). According to Goodman (1973), however, if an appeal to the notion of a divine planner is made, the plan for (34) may be retained: if there is a divine plan controlling the movement of the heavens, sentences like (34) might be acceptable.

(34) \# The sun is setting at 8:39 tomorrow. (Goodman (1973), Wekker (1976, pp. 108-109), Huddleston (1977), Prince (1982) with a slight modification, Leech (1987, p.64, 2004, p. 63) with a slight modification)

When the situation can be viewed as cognitively 'in progress' by the speaker, examples like (34) come to be acceptable. And, in this case, the situation of the sun-set-at 8:39-tomorrow is not usually regarded as cognitively 'in progress,' so that, as Huddleston \& Pullum (2002) state, examples like (34) should be commonly judged as anomalous.

Next, based on Langackerian Cognitive Grammar, we will provide an analysis for the 'future use' like (28)-(33). According to Langacker $(1987,2001)$, language is "an integral part of human cognition" (Langacker, 1987, p. 12), and grammar is "claimed to be in symbolic in nature. A symbolic structure is defined as the linking of a form (i.e. a phonological structure) and a meaning (a semantic structure)." (Langacker, 2001, p. 252) In Langacker's (2008) Cognitive Grammar, a verb profiles a process. The term "process" is adopted for "a complex relationship that develops through conceived time and is scanned sequentially." (Langacker, 2008, p. 112) The profile is to direct attention to a particular substructure (see Langacker, 2008, p. 66). Figure 1 below represents a process.

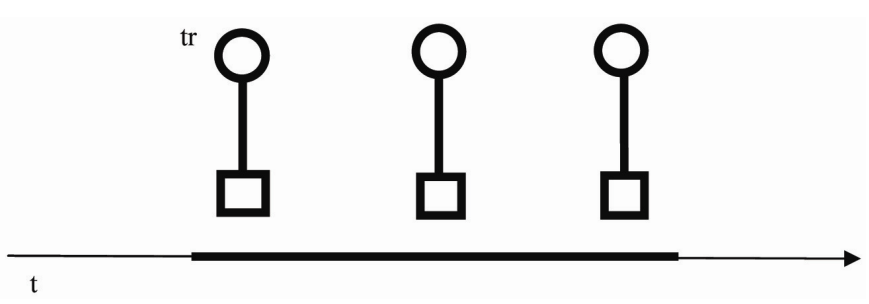

Figure 1. Verb (Langacker (2008, p. 119))

In Figure 1 relationships are depicted by lines connecting the entities (described as squares) with the things (described as circles). In Figure 1 the trajector (tr) is the most prominent participant and can be characterized as the primary focus within the profiled relationship (Langacker, 2008, p. 70). The arrow in Figure 1 represents conceived time (t), that is, time as an object of conception (Langacker, 2008, p. 110).

In Cognitive Grammar, the so-called ing-participle takes "an 'internal perspective' on the verbal process." (Langacker, 2008, p. 120) According to Langacker (2008), in a construction like (35) below the ing-participle "profiles a complex relationship, whose characteristic feature is that it represents an internal portion of some longer process." This is illustrated as Figure 2, where "the beginning and end of the verbal process lie outside the immediate temporal scope, which delimits the relationship profiled by the participle."

(35) A monkey is climbing the tree. (Langacker, 2008, p. 120)

In Figure 2, a limited immediate scope (IS) refers to the portion directly relevant for a particular purpose. In Langacker's CG, the immediate scope can be described as the "onstage region," the general region of viewing attention (Langacker, 2008, p. 63). 


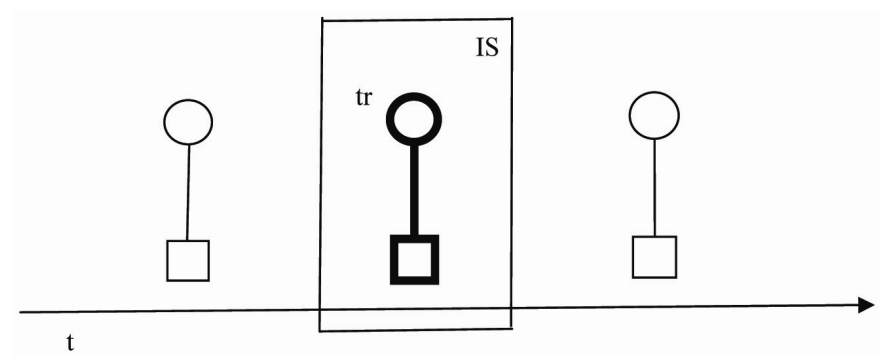

Figure 2. Langacker (2008, p. 121) with a slight modification

In this way, according to Langacker (2008), Figure 2 shows the ing-participle in a construction like (35). At this point, we assume that Figure 3 shows the 'future use' of the progressive. That is, we posit that in the 'future use' of the progressive the profiled relationship is posterior to the time of speaking. This is a way of accounting for the 'future use' on the basis of the framework of Langacker's CG.

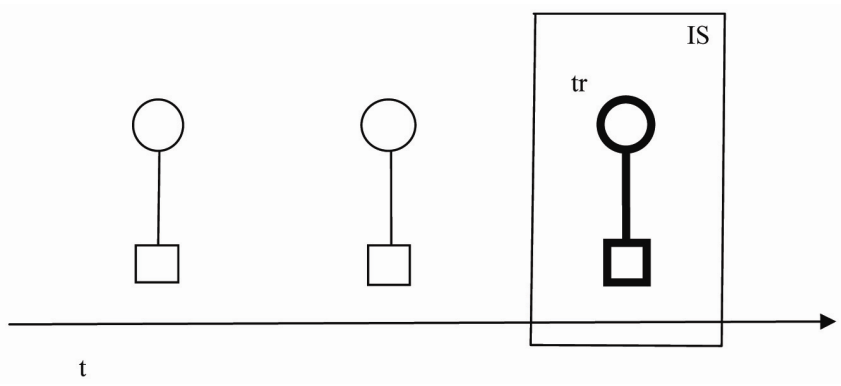

Figure 3. The 'future use' of the progressive

The reason why in the 'future use' of the progressive the situation can be viewed as 'in progress' is that the 'future use' is based on the same cognitive foundation as the use of ongoing activities is. The difference between the 'future use' and the use of ongoing activities consists in where the profiled relationship is positioned. (Note 14) As is shown in Figure 2, in the use as progressive aspect marker the profiled relationship is positioned at the speech time. As is shown in Figure 3, on the other hand, in the 'future use' the profiled relationship is situated after the speech time. Assuming that the 'future use' is illustrated in Figure 3, we can see that the speaker views the situation as cognitively in progress in the 'future use' as well as the progressive aspect use.

Next, observe sentences (36)-(37) below. They express temporary habits (see Comrie (1976, p. 37), Bybee \& Dahl (1989, p. 82), Kranich (2013, p. 12)).

(36) He is working on his book every day. (Bybee \& Dahl, 1989, p. 82)

(37) I am taking Finnish lessons this month. (Rydén, 1997, p. 423)

According to Kranich (2013), the ing-expressions of temporary habits "can be seen as an extended application of the progressive meaning, as this type of use is not clearly different in kind from other uses of progressive aspect." Kranich (2013), furthermore, states that in the use of the construction for temporary habits, "the situation can be viewed as dynamically in progress." Therefore, we can say: although examples (36)-(37) do not indicate progressive aspect, the situation is viewed as in progress by the speaker.

It seems that to both native speakers of English and non-native speakers of English, it is more understandable that the situation is viewed as cognitively in progress in examples (36)-(37) than in the 'future use' of the present progressive. As the situation is viewed as in progress in examples like (36)-(37), the situation is viewed as in progress in the 'future use.' In the 'future use' the situation which is viewed as in progress is applied to an event in the future, as illustrated in Figure 3.

\section{Concluding Remarks}

The present paper has formulated that the progressive form with future time reference, historically, followed the progressive as progressive marker. And in this paper it was claimed that the 'future use' of the present progressive is a case of the diachronic phenomenon called subjectification. This paper has, furthermore, argued 
that in the 'future use' of the progressive the situation can be viewed as cognitively 'in progress,' and has accounted for the 'future use' in terms of Langacker's Cognitive Grammar. More specifically, the 'future use' is based on the same cognitive foundation as the use of progressive aspect marker is. And the difference consists in where the profiled relationship is positioned: in the use of progressive aspect marker the profiled relationship is at the speech time, and in the 'future use' it is situated posterior to the speech time. In addition, the progressive forms which represent temporary habits can also be viewed as 'in progress' cognitively. In this way, progressives are involved with our various cognitions.

\section{Acknowledgments}

I am truly grateful to two anonymous reviewers for their comments which led to a revision of this paper. I would also like to express my gratitude to Naoaki Wada, Keita Ikarashi, Ryohei Naya, and Masatoshi Honda for their valuable comments on an earlier version of the paper.

\section{References}

Aijmer, K. (1985). The semantic development of Will. In J. Fisiak (Ed.), Historical Semantics and Historical Word Formation, 11-21. Berlin: Mouton. http://dx.doi.org/10.1515/9783110850178.11

Allen, R. L. (1966). The Verb System of Present-day American English. The Hague: Mouton \& Co.

Benveniste, E. (1971). Subjectivity in language. Problems in General Linguistics, 223-230. Trans. by Mary Elizabeth Meek. FL: University of Miami Press, Coral Gables, (Original French publication, 1958).

Bergs, A. (2010). Expressions of futurity in contemporary English: a construction grammar perspective. English Language and Linguistics, 14(2), 217-238. http://dx.doi.org/10.1017/ s1360674310000067

Biber, D., Johansson S., Leech, G., Conrad, S., \& Finegan, E. (1999). Longman Grammar of Spoken and Written English. London: Longman.

Brinton, L. \& Traugott, E. C. (2005). Lexicalization and Language Change. Cambridge: Cambridge University Press.

Brinton, L. (2008). The Comment Clause in English. Cambridge: Cambridge University Press. http://dx.doi.org/10.1017/CBO9780511551789

Bybee, J., \& Dahl, Ö. (1989). The creation of tense and aspect systems in the languages of the world. Studies in Language, 13(1), 51-103. http://dx.doi.org/10.1075/sl.13.1.03byb

Bybee, J., Perkins, R., \& Pagliuca, W. (1994). The Evolution of Grammar. Chicago and London: The University of Chicago Press.

Campbell, L. (2001). What's wrong with grammaticalization?. Language Sciences, 23, 113-161. $\mathrm{http} / / / \mathrm{dx}$.doi.org/10.1016/S0388-0001(00)00019-X

Close, R. A. (1975). A Reference Grammar for Students of English. London: Longman.

Comrie, B. (1976). Aspect. An Introduction to the Study of Verbal Aspect and Related Problems. Cambridge: Cambridge University Press.

Dahl, Ö. (2000). The grammar of future time reference in European languages. In Ö. Dahl (Ed.), Tense and aspect in the languages of Europe (pp. 309-328). Berlin and New York: Mouton de Gruyter. http://dx.doi.org/10.1515/9783110197099.2.309

De Wit, A., \& Brisard F. (2014). A Cognitive Grammar account of the semantics of the English present progressive. Journal of Linguistics, 50, 49-90. http://dx.doi.org/10.1017/ s0022226713000169

Declerck, R. (1991). A Comprehensive Descriptive Grammar of English. Tokyo: Kaitakusha.

Declerck, R. (in cooperation with Susan Reed and Bert Cappelle). (2006). The Grammar of the English Verb Phrase Volume 1: The Grammar of the English Tense System. Berlin and New York: Mouton de Gruyter.

Denison, D. (1993). English Historical Syntax: Verbal Constructions (Longman Linguistics Library). London and New York: Longman.

Dixon, R. M. W. (2005). A Semantic Approach to English Grammar. Oxford: Oxford University Press.

Dowty, D. R. (1977). Toward a semantic analysis of verb aspect and the English 'imperfect' progressive. Linguistics and Philosophy, 1, 45-77. http://dx.doi.org/10.1007/BF00351936

Fitzmaurice, S. (1998). Grammaticalization, textuality and subjectivity: the progressive and the Anglo-Saxon chronicle. In D. Stein \& R. Sornicola (Eds.), The Virtues of Language. History in Language, Linguistics and 
Texts (pp. 21-49). Amsterdam and Philadelphia: John Benjamins.

Fries, C. C. (1956). Expression of the future. Language Learning, 7, 125-133. http://dx.doi.org/10.1111/j.1467-1770.1956.tb01207.x

Goodman, F. (1973). On the semantics of futurate sentences. Working Papers in Linguistics, 16, 76-89. Columbus, OH: Ohio University Press.

Goossens, L. (1994). The English progressive tenses and the layered representation of functional Grammar. In C. Vet \& C. Vetters (Eds.), Tense and Aspect in Discourse (pp. 161-177). Berlin and New York: Mouton de Gruyter. http://dx.doi.org/10.1515/9783110902617.161

Harris, A. C., \& Campbell, L. (1995). Historical Syntax in Cross-Linguistic Perspective. Cambridge: Cambridge Universitry Press.

Hirtle, W. H. (1967). The Simple and Progressive Forms: An Analytical Approach. Quebec: Presses de l'Université Laval.

Hirtle, W. H., \& Curat, V. N. (1986). The simple and the progressive: 'future' use. Transactions of the Philological Society, 84, 42-84. http://dx.doi.org/10.1111/j.1467-968X.1986.tb01047.x

Hopper, P. J., \& Traugott, E. C. (2003). Grammaticalization (2nd ed.). Cambridge: Cambridge University Press. http://dx.doi.org/10.1017/CBO9781139165525

Huddleston, R. (1977). The futurate construction. Linguistic Inquiry, 8, 730-736. Retrieved from http://www.jstor.org/stable/i390189

Huddleston, R., \& Pullum, G. K. (2002). The Cambridge Grammar of the English Language. Cambridge: Cambridge University Press.

Hundt, M. (2004). Animacy, agentivity, and the spread of the progressive in modern English. English Language and Linguistics, 8(1), 47-69. http://dx.doi.org/10.1017/S1360674304001248

Jespersen, O. (1924). The Philosophy of Grammar. London: George Allen \& Unwin.

Kranich, S. (2006). Subjective progressives in seventeenth and eighteenth century English. In M. Gotti, M. Dossena, \& R. Dury (Eds.), English Historical Linguistics 2006, Volume I : Syntax and Morphology (pp. 241-256). Amsterdam and Philadelphia: John Benjamins.

Kranich, S. (2010). Grammaticalization, subjectification and objectification. In K. Stathi, E. Gehweiler, \& E. König (Eds.), Grammaticalization. Current Views and Issues (pp. 101-121). Amsterdam and Philadelphia: John Benjamins. http://dx.doi.org/10.1075/slcs.119.07kra

Kranich, S. (2013). Functional layering and the English progressive. Linguistics, 51(1), 1-32. $\mathrm{http}: / / \mathrm{dx}$.doi.org/10.1515/ling-2013-0001

Kruisinga, E. (1931). A Handbook of Present-day English. Groningen: Noordhoff.

Langacker, R. W. (1987). Foundations of Cognitive Grammar, 1. Stanford CA: Stanford University Press.

Langacher, R. W. (2001). The English present tense. English Language and Linguistics, 5(2), 251-272. http://dx.doi.org/10.1017/S1360674301000235

Langacher, R. W. (2008). Cognitive Grammar: A Basic Introduction. Oxford: Oxford University Press. http://dx.doi.org/10.1093/acprof:oso/9780195331967.001.0001

Leech, G. (1971). Meaning and the English Verb (1st ed.). London: Longman.

Leech, G. (1987). Meaning and the English Verb (2nd ed.). London: Longman.

Leech, G. (2004). Meaning and the English Verb (3rd ed.). London: Longman.

Leech, G., \& Svartvik, J. (1994). A Communicative Grammar of English (2nd ed.). London and New York: Longman.

Leech, G., \& Svartvik, J. (2002). A Communicative Grammar of English (3rd ed.). London and New York: Longman.

Leech, G., Cruickshank, B., \& Ivanic, R. (2001). An A-Z of English Grammar \& Usage. London: Longman.

Leech, G., Hundt, M., Mair, C., \& Smith, N. (2009). Change in Contemporary English: A Grammatical Study (Studies in English Language). Cambridge: Cambridge University Press. http://dx.doi.org/10.1017/CBO9780511642210 
Lehmann, C. (1995). Thoughts on Grammaticalization. Munchen and Newcastle: Lincom Europa.

Lyons, J. (1977). Semantics II. Cambridge: Cambridge University Press.

Lyons, J. (1995). Linguistic Semantics: An Introduction. Cambridge: Cambridge University Press. http://dx.doi.org/10.1017/CBO9780511810213

Michaelis, L. A. (2004). Type shifting in construction grammar: an integrated approach to aspectual coercion. Cognitive Linguistics, 15(1), 1-67. http://dx.doi.org/10.1515/cogl.2004.001

Nesselhauf, N. (2007). The spread of the progressive and its 'future' use. English Language and Linguistics, 11(1), 191-207. http://dx.doi.org/10.1017/S1360674306002152

Nickel, G. (1966). Die Expanded Form im Altenglischen. Vorkommen, Funktion und Herkunft der Umschreibung boen/wesan + Partzip Prasens. Neumunster: Karl Washholtz.

Palmer, F. R. (1987). The English Verb (2nd ed.). London: Longman.

Palmer, F. R. (1990). Modality and the English Modals (2nd ed.). London: Longman.

Palmer, F. R. (2001). Mood and Modality (2nd ed.). Cambridge: Cambridge University Press. http://dx.doi.org/10.1017/CBO9781139167178

Palmer, F. R. (2003). Modality in English: theoretical, descriptive and typological issues. In R. Facchinetti, M. Krug, \& F. R. Palmer (Eds.), Modality in Contemporary English (pp. 1-17). Berlin: Mouton de Gruyter. http://dx.doi.org/10.1515/9783110895339.1

Poutsma, H. (1926). A Grammar of Late Modern English, Part 2. Groningen: Noordhoff.

Prince, E. F. (1982). The simple futurate: not simply progressive futurate minus progressive. CLS, 18, 453-465.

Quirk, R., Greenbaum, S., Leech, G., \& Svartvik, J. (1985). A Comprehensive Grammar of the English Language. London: Longman.

Radden, G., \& Dirven, R. (2007). Cognitive English Grammar. Amsterdam and Philadelphia: John Benjamins.

Rissanen, M. (1999). Syntax. In R. Lass (Ed.), The Cambridge History of the English Language, 3, 1476-1776. Cambridge: Cambridge University Press.

Rydén, M. (1997). On the panchronic meaning of the English progressive. In T. Nevalainen \& L. Kahlas-Tarkka (Eds.), To explain the present: studies in the changing English language in honour of Matti Rissanen (pp. 419-429). Helsinki: Société Néophilologique.

Schwenter, S. A., \& Traugott, E. C. (2000). Invoking scalarity: the development of In Fact. Journal of Historical Pragmatics, 1(1), 7-25. http://dx.doi.org/10.1075/jhp.1.1.04sch

Smith, C. S. (1981). The futurate progressive: not simply future + progressive. CLS, 17, 369-382.

Smith, C. S. (1997). The Parameter of Aspect (2nd ed.). Dordrecht: Kluwer Academic Publisher. http://dx.doi.org/10.1007/978-94-011-5606-6

Talmy, L. (1996). Fictive motion in language and 'ception'. In P. Bloom, M. A. Peterson, L. Nadel \& M. F. Garrett (Eds.), Language and Space (pp. 211-276). Cambridge: MIT Press.

Talmy, L. (2000). Toward a Cognitive Semantics, 1. Cambridge: MIT Press.

Traugott, E. C. (1989). On the rise of epistemic meaning in English: an example of subjectification in semantic change. Language, 65, 31-55. http://dx.doi.org/10.2307/414841

Traugott, E. C. (1995). Subjectification in grammaticalization. In D. Stein \& S. Wright (Eds.), Subjectivity and Subjectification. Linguistic Perspectives (pp. 31-54). Cambridge: Cambridge University Press.

Traugott, E. C. (2003). From subjectification to intersubjectification. In R. Hicky (Ed.), Motives for Language Change (pp. 124-139). Cambridge: Cambridge University Press. http://dx.doi.org/10.1017/CBO9780511486937.009

Traugott, E. C. (2010). (Inter)subjectivity and (inter)subjectification: a reassessment. In K. Davidse, L. Vandelanotte, \& H. Cuyskens (Eds.), Subjectification, Intersubjectification, and Grammaticalization (pp. 29-71). Berlin and New York: Mouton De Gruyter. http://dx.doi.org/10.1515/9783110226102.1.29

Traugott, E. C., \& Dasher, R. B. (2002). Regularity in Semantic Change. Cambridge: Cambridge University Press.

Traugott, E. C., \& König, E. (1991). The semantics-pragmatics of grammaticalization revisited. In E. C. Traugott 
\& B. Heine (Eds.), Approaches to Grammaticalization (vol. 1, pp. 189-218). Amsterdam and Philadelphia: John Benjamins. http://dx.doi.org/10.1075/tsl.19.1.10clo

Visser, F. T. (1963-73). A Historical Syntax of the English Language. Leiden: E. J. Brill.

Wada, N. (2009). Present progressive with future time reference vs. be going to: Is Doc Brown going back to the future because he is going to reconstruct it? English Linguistics, 26, 96-131. http://dx.doi.org/10.9793/elsj.26.1_96

Warner, A. R. (1995). Predicting the progressive passive: parametric change within a lexicalist framework. Language, 71, 533-557. http://dx.doi.org/10.2307/416219

Wekker, H. C. (1976). The Expression of Future Time in Contemporary British English. Amsterdam: North-Holland.

Wright, S. (1994). The mystery of the modal progressive. In D. Kastovsky (Eds.), Studies inEarly Modern English (pp. 59-77). Berlin and New York: Mouton de Gruyter. http://dx.doi.org/10.1515/9783110879599.467

Žegarac, V. (1993). Some observations on the pragmatics of the progressive. Lingua, 90, 201-220. http://dx.doi.org/10.1016/0024-3841(93)90067-7

\section{Dictionaries}

COBUILD ${ }^{4}$ : Collins COBUILD Advance Learner's English Dictionary (4th ed.). 2003. Birmingham: HarperCollins.

$L D C E^{3}$ : Longman Dictionary of Contemporary English (3rd ed.). 1995. London: Longman.

OALD ${ }^{6}$ : Oxford Advanced Learner's Dictionary (6th ed.). 2000. Oxford: Oxford University Press.

OED ${ }^{2}$ : Oxford English Dictionary (2nd ed.). 1989. Oxford: Oxford University Press.

\section{Notes}

Note 1. The simple present tense can be used to refer to future events, as follows:

(i) The semester starts on 1st February. (Leech, 2004, p. 65)

Note 2. As Leech et al. (2001, p. 175) too put it, future plans or arrangements referred to by the progressive are not so fixed in comparison with the simple present tense.

(ii) We are starting for Istanbul tonight. (Leech, 2004, p. 65)

(iii) We start for Istanbul tonight. (Leech, 2004, p. 65)

According to Leech $(2004$, p. 65), sentence (i) above indicates a present plan which could be possibly altered later. In sentence (ii), however, changing the plan is "out of the question."

Note 3. With regard to the characterization of the 'future use,' for example, Declerck (1991, p. 92, 2006, p. 184) states that: "when a future situation is referred to by the present continuous (the progressive form of the present tense), it is represented as resulting from a present plan or arrangement." Radden \& Dirven (2007, p. 226), on the other hand, call the use of the present progressive with future reference the "planned future" and state: "the planned future applies to future events for which arrangements have been made in the present." In addition, Wekker (1976, pp. 108-109) observes that "the progressive can be used only when the future is felt to be one that has been planned or prearranged by some human agents."

Note 4. There are a number of examples where the expressive effect is simply the intent of the subject. For example:

(i) Aubrey, well, she's going to town, Cayley says here, and his visit is at an end. He's coming over this morning to call on you. (Fries, 1956, p. 131 in Hirtle \& Curat, 1986, p. 73)

According to Hirtle \& Curat (1986, p. 73), "any other arrangements are simply ignored here."

Note 5. Wada (2009) explains why sentences containing the present progressive with future time reference can represent 'arrangement,' 'plan,' 'intention,' or 'decision.' But what motivates a study like this is the concept of subjectification.

Note 6. With reference to the simple present tense signifying a plan or arrangement, Leech $(2004$, p. 65$)$ 
describes a use of the simple present like this as "future assumed to be fact." At this point, since the future present tense is assumed to be fact, we can state that the simple present tense signifying a plan or arrangement is not related to the diachronic phenomenon of subjectification.

Note 7. Traugott (2010) states that subjectification is the mechanism by which: "meaning are recruited by the speaker to encode and regulate attitudes and beliefs." (Traugott, 2010, p. 35) Thereby, we can see that Traugott's (2010) way to define subjectification is more general and abstract than Traugott's (1995); in other words, the definition of subjectification by Traugott (1995) is more reader-friendly than that by Traugott (2010).

Note 8. Strictly speaking, Traugott \& Dasher (2002, p. 225) and Traugott $(2003,2010)$ argue that the semantic change of expressions can be generally organized, as follows:

(i) non-/less subjective $>$ subjective $>$ intersubjective

However, the phenomenon dealt with in the present paper are not related to intersubjectivity and intersubjectification.

Note 9. Traugott \& König (1991) state that, with respect to the concessive while in the sense of 'although,' the pragmatics of the speaker's belief-state is strengthened.

Note 10. With respect to subjectification, furthermore, according to Traugott (2010), a bit of was subjectified from a Partitive 'morsel, unit bitten out' to a Quantifier (endowed with quantificational scalar meaning 'somewhat,' a 'downtoning' or understating meaning like that of a little). In addition, Traugott (2010) has argued that subjectification is independent of processes of grammaticalization, but there is inevitably a close interaction between grammaticalization and subjectification for reasons relating to the various functions of grammar.

Note 11. According to Nesselhauf (2007, p. 198), "most substantial increase in progressives with future time reference has taken place in speech-based registers of drama and fiction conversation. ... In the more formal written text types (fiction prose, newspaper reportage, sermons, medical writing, and science writing), on the other hand, practically no increase can be observed." And also, Nesselhauf (2007) states that the increase in progressives with future time reference is observed more strikingly in speech-based and informal written registers than in formal written ones (cf. Leech et al. (2009, p. 132)).

Note 12. Progressive forms tend to be accompanied by an emotive overtone, usually of disapproval, when emphasized by an adjunct such as always, continually, constantly, forever, or perpetually (see Declerck (1991), Huddleston \& Pullum (2002)). Look at:

(i)They're always meeting at the market. (Huddleston \& Pullum, 2002, p. 166)

(ii)The baby is always crying. (Žegarac, 1993, p. 212)

A use in the present progressive like (i) and (ii) above is more subjective than the use of ongoing activities (cf. Wright (1994), Kranich (2006, pp. 244-246, 2013, p. 8)). In fact, Leech et al. (2009, p. 131) state that the progressive modified by such an adverb as always shows a high degree of subjective expression of the speaker's attitude, and Žegarac (1993) states that (ii) is really strongly felt as expressing the speaker's attitude toward the situation described, such as annoyance, nervousness, dissatisfaction and the like. At this point, note that the term "the speaker's attitude" is used. It is, thus, plausible to say that the present progressive like (i) and (ii) is a case of subjectification, that is to say, a use of the progressive as in (i) and (ii) is subjectified.

Note 13. Allen (1996, p. 215) says "that the present progressive form often seems to refer to a future event for which preparations of some kind already have begun." Poutsma (1926, p. 355), on the other hand, maintains that when the progressive is used, "the preparations for the action are then thought of as in progress."

Note 14. De Wit \& Brisard (2014, p. 71) considers the 'future use' of the present progressive as one type of extension of "Current Ongoingness."

\section{Copyrights}

Copyright for this article is retained by the author(s), with first publication rights granted to the journal.

This is an open-access article distributed under the terms and conditions of the Creative Commons Attribution license (http://creativecommons.org/licenses/by/3.0/). 